\title{
The Democratic Party OF MATTEO RENZI
}

\author{
Mattia Guidi
}

The rise of Matteo Renzi, who became prime minister in February 2014, is certainly the most significant political event of the year. His election as leader of the Partito Democratico (PD, Democratic Party) in December 2013 "shook" and rapidly transformed the Italian political environment. Renzi's action has affected various aspects of Italian politics: the nature and the platform of the PD, the relationship between Italy and the other European countries, and the strength and reform capacity of the executive. Although it is still too early to draw conclusions about the long-term impact of Renzi's leadership (in the PD and in the country in general), it is possible to map the key novelties that he introduced and their short- and medium-term implications.

This chapter will analyze the impact of Renzi's action on the PD, looking at both its internal organization and its activity and position in the party system. Although the study will seek to distinguish the party from its leader, it is evident that Renzi's leadership has fundamentally changed the way in which the PD discusses, decides, and acts. Much more than in the past, the party has come to identify with its leader, even more since Renzi has become prime minister. It is therefore crucial to assess if Renzi is introducing structural changes in the PD and in the party system.

The remainder of this chapter proceeds as follows. First, it analyzes how Renzi has seized the party and how he is steering it. The next section assesses the way in which Renzi's leadership has changed the 
relationship between the PD and other societal actors. The following section illustrates the shift that the prime minister has brought about in the party's attitude toward the European Union and the other EU member states. Lastly, the chapter describes Renzi's impact on the nature and the agenda of the executive and on the PD's position in the party system.

\section{Renzi’s Democratic Party: Internal Organization and Decision-Making}

Many of the changes that Renzi has introduced in Italian politics stem from the shift that took place in the Democratic Party at the end of 2013. In terms of its development and consequences, Renzi's election as the PD secretary showed two main peculiarities. First, the election of the secretary with a very large majority (68 percent of the votes) was not, as in the past, the result of a choice made inside the party. ${ }^{1}$ Previous PD secretaries selected by similar so-called primaries, ${ }^{2}$ Walter Veltroni in 2007 and Pier Luigi Bersani in $2009,{ }^{3}$ had both been supported by a majority of the party elite. In the case of Renzi, he ran and won against the coalition that supported Bersani and interim secretary Guglielmo Epifani. The second distinct feature of Renzi's election was that, for the first time, the elected party leader was someone who had never been a member of the Communist Party. Given that former Communists have always been majoritarian in the party (and in its electorate), it seemed inevitable that the secretary would be chosen from among them. Renzi's election, therefore, showed an unexpected volatility in the PD's electorate. How can this be explained? On the one hand, this was the outcome of the general fluidity that has affected the Italian electorate in recent years. ${ }^{4}$ On the other hand, the electorate's inconstancy was encouraged by the volatility of the party elite itself. After Bersani's "non-victory" in 2013, many who had supported him realized that most PD voters would no longer back anyone from the "old guard" and adjusted their position accordingly. Needless to say, Renzi's attempt was successful because the PD has rules and procedures that allow candidates to bypass the party elite consensus, if they wish to do so. The leader is ultimately chosen by the voters, not by party members.

If one looks at the output of Renzi's party leadership in terms of electoral consensus, his results have been astonishing. As figure 1 shows, when Renzi became secretary, pollsters estimated that little more than 30 percent of the voters would choose the PD. The already 
FIGURE 1 Average Electoral Consensus for the Democratic Party, January-October 2014

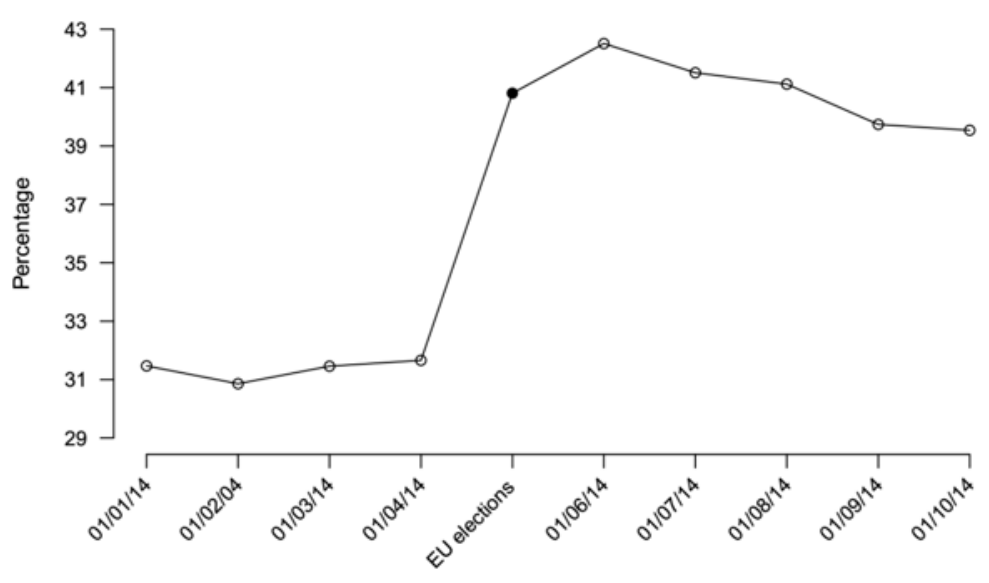

Note: Empty dots indicate estimated consensus. The black dot is the European election result.

Source: Termometro Politico (termometropolitico.it).

significant growth (around 5 percent) that the party had experienced since the February 2013 general election was mainly due to the media visibility granted by the election of the new secretary. Renzi's election, as well as his appointment as prime minister, did not seem to be reflected in the polls. ${ }^{5}$ As Bressanelli (this volume) notes, the strength of the PD's success at the European elections was totally unexpected and not predicted by any poll. During the rest of the year, the PD's estimated share of the votes has remained high, quite close to the 40.8 percent reached in May. The reasons for this rise in consensus cannot be analyzed here, but it does not seem to be a volatile increase. Although there has been a slow but steady decline of electoral support for Renzi and the PD after May, the overall consensus appears to go well beyond a honeymoon period for the government led by the secretary.

Looking more closely at Renzi's impact on the internal organization of the PD, the most relevant novelty is his "presidential" style of leadership. Although he has involved in the secretariat (the working group that helps the secretary develop his proposals on a variety of issues) party members who had not supported him in the past, the impact of the dissenting factions on the decisions made by the party has been very limited so far. Both in defining the party's platform in the first months after his election and even more as prime minister 
since February, he has often made decisions by asking the party board (where the leadership election gave him an overwhelming majority) to back his proposals without consulting the minority. The first example of this method was the reform of the electoral system, a first draft of which was agreed on by Renzi and Silvio Berlusconi in January. On that occasion, as well as others, Renzi asked the board to accept his proposal as it was formulated-a sort of take-it-or-leave-it offer. ${ }^{6}$ Since he has become prime minister, this practice has further increased, as Renzi can take advantage of his much stronger agenda-setting powers. While this has not created serious problems when a given proposal resonates values shared by all factions of the PD (as in the case of the 80 euro tax bonus for low-salary earners, adopted in May), the minority has openly contested the prime minister's proposals when they were perceived as too divergent from the party's traditional ideology.

As noted above, Renzi has always had little to fear from the board, even when the minority has voted against a proposal or abstained. Sometimes Renzi has agreed to amend his proposals marginally, but this is the extent of the limited influence that the minority has been able to assert. The groups in Parliament, instead, reflect Bersani's victory in the 2012 primaries. For this reason, the relationship with the "party in Parliament" has been characterized by a higher degree of conflict. Strong opposition has been voiced in the party groups (both in the Chamber and in the Senate) on the reforms of the electoral system, the Constitution, and the labor market, to name but a few. This explains why the Renzi Cabinet has so frequently called for confidence votes on its draft bills. It did so 24 times in its first 243 days in officeroughly one confidence vote every 10 days. $^{7}$

Another radical innovation that characterizes Renzi's leadership is the use he makes of live broadcasting during the sessions of the party board. Although live broadcasting had always been used for the party assembly (which convenes twice a year), the PD started to broadcast its party board meetings only after the 2013 election. This practice was a reaction to the success of (and a sort of appeasement toward) Beppe Grillo's Five Star Movement, which advocated full transparency for every stage of policy-making. Not only has Renzi decided to continue to broadcast the board meetings, but he has managed to get the most out of them, both in ideal and practical terms. In terms of ideals, live broadcasting is useful to Renzi's discourse in that it reflects his notion of an "open" party, where everything is debated in full transparency. More practically, since he knows that on several issues he has more consensus outside than inside the party, live broadcasting allows him to use the general audience as leverage to push the minority toward his positions. Capitalizing on the Italian populace's 
general disaffection with political debates, he can present himself as the one who tries to get things done, while his opponents can be easily depicted as talkative and ineffective.

\section{Renzi's Democratic Party: Ideology and Relationships with Other Societal Actors}

What is the ideology of Renzi's PD? The question is more complicated than it would initially appear for two main reasons. First, as shown in the previous section, the current PD's platform relies heavily, much more than in the past, on the leadership of its secretary. This suggests that the "boundaries" of party ideology are rather blurred and can be continuously redefined by the party leadership. ${ }^{8}$ This implies a second distinctive feature of Renzi's PD: its mutable nature allows it to attract voters from a wide political spectrum-like an ideal-typical catch-all party. ${ }^{9}$ The only relevant electoral test for the party, the European elections in May, showed that the PD was able to maintain all its traditional, more leftist voters, managing at the same time to acquire many centrist and right-wing voters. ${ }^{10}$ All in all, the present-day PD can be defined as more centrist than in the past (under Bersani's leadership in particular), in that Renzi challenges several traditional leftist issues, such as the government's relationship with the trade unions, the refusal of the "presidentialization" of politics, and the support of public funding for political parties.

Two examples of the PD's shift toward the center are the constitutional and electoral system reforms, on the one hand, and the labor market reform, on the other. Regarding the first two reforms, their main consequences would be (a) assuring a majority of seats to the winning party or coalition, (b) reducing the number of parties in Parliament, and (c) enhancing the powers of the government in the constitutional system. All of these goals are explicitly opposed by parties and movements of the left, by a number of prominent Italian scholars (mainly constitutional law professors), and even by members of the PD. The origins of the opposition to this project can be traced to the traditional (Italian) Communist preference for a very strong Parliament vis-à-vis the government, as well as for highly proportional electoral systems as opposed to majoritarian representation. This predisposition was further strengthened by Berlusconi's numerous (and failed) attempts to enhance the government's powers in the institutional system. For a large part of the Italian left, Renzi's constitutional reform projects are seen as a continuation of Berlusconi's and must be opposed accordingly. 
Also regarding the relationship with trade unions, especially the leftist CGIL (Italian General Confederation of Labor), Renzi shifted away from the PD's traditional stance. Although the positions of the centerleft parties and CGIL were not always perfectly aligned in the last two decades, the tie had never been broken (suffice it to note that several prominent members of the PD, including former secretary Epifani, come from this union). Bersani's PD did not always explicitly back CGIL, but it always tried to accommodate the union's demands. Renzi instead appears to have a clear strategy of cutting every connection with the trade unions. He does not believe in consociationalism and explicitly rejects a pluralist approach to decision-making. ${ }^{11}$ This has become evident with the labor market reform passed on 4 December, with almost no consultation with employers and trade unions. The fact that the CGIL secretary, openly compared Renzi to Margaret Thatcher, called for a big demonstration in October and for a general strike in December against the government's labor policy indicates how deep the distance is between the two actors at the moment. ${ }^{12}$

This apparent disconnection between the PD and a significant part of the center-left electorate raises the question of how Renzi was successful in convincing the PD's traditional leftist voters on a number of issues despite the fact that his position shifted significantly to the center. To answer this question, a practical and an ideological explanation can be advanced. In practical terms, Renzi managed to portray himself as a leader who could lead the PD to win elections outright, rather than having to govern in large and fragmented coalitions. Since 1992, centerleft voters had experienced either electoral defeats or victories with big coalitions that had proved too polarized and unstable, resulting in weak and short-lived governments. Speaking in rational choice language, many leftist voters may have considered that Renzi's lesser fit with their position was compensated for by his greater chances to win elections and actually adopt at least some of their most important policies.

In ideological terms, Renzi is smart enough not to repudiate the word "left." Quite the contrary, he has openly argued that the PD must not be afraid of defining itself as a party of the left. ${ }^{13}$ In the speech he gave after his victory in the party leadership elections, he stated that "this is not the end of the left: it is the end of a certain establishment of the left." 14 It is ironic to observe that Renzi (the PD's first non-Communist and non-socialist secretary) succeeded in convincing the PD to join the Group of the Party of European Socialists (PES Group). This signals a two-fold strategy: on the one hand, it reaffirms that the political space that the party wants to cover is the left in its broader sense; on the other hand, it redefines what the term "left" means today. In several instances, Renzi has claimed that the left must innovate, not 
simply preserve what has been built in the past. As he put it: "A party of the left must imagine the future, not just wait for it." ${ }^{15}$ Renzi uses this rhetoric to push toward a modernization of the economic system, which in his view entails dismantling some privileges enjoyed by traditional center-left constituencies as well.

\section{Renzi's Democratic Party and the European Union}

Italy's relationship with the European Union has always been complex and ambivalent. The country has long shown strong support for European integration, ${ }^{16}$ although it has declined in the last two decades, as in most EU member states. ${ }^{17}$ Well beyond the era of "permissive consensus," 18 Italian executives have often used the EU, in a sort of two-level game, as an "external constraint" 19 in order to push reluctant parties and societal actors (trade unions above all) to accept retrenchment and structural reforms, particularly with regard to the country's participation in the Economic and Monetary Union. ${ }^{20}$ It is usually acknowledged that these reforms were necessary anyway, but the EU gave Italian governments a chance to "shift the blame" for the high costs that the reforms imposed, in the short run, on the electorate. ${ }^{21}$

In terms of left-right competition, the Italian center-left has been traditionally more pro-EU than the center-right. ${ }^{22}$ The "external constraint" has therefore been used in different ways by the two main coalitions: while the center-left has framed it as an opportunity to improve the Italian system, the center-right has often complied more reluctantly with EU inputs. Technocratic governments, not surprisingly, have strongly relied on the support coming from EU institutions. Mario Monti, probably because he was unconstrained by both political parties and social actors, ${ }^{23}$ was the first to argue explicitly that austerity was not necessary because the EU wanted it, but because it was "in our children's best interests." 24 Enrico Letta espoused a similar framing, stressing that fiscal discipline must not be adopted because someone imposes it, but because Italy is "an adult country that wants to return to building its children's future." 25

In Italy's relationship with Europe, Renzi has combined the traditional center-left pro-EU rhetoric with a more active and combative approach to EU issues, which has certainly attracted traditional rightwing voters. While Monti and Letta mainly regarded Europe as an entity that Italy could only marginally influence, Renzi envisages a different role for Italy, which (in his words) should be "a leader, not a follower" in Europe. ${ }^{26}$ This strategy was boosted by the PD's victory in the European elections (see Bressanelli, this volume). Having joined 
the PES before the elections, the PD turned out to be the most-voted party in the group and obtained the presidency of the parliamentary group. This result is not trivial, as the PES Group is very likely to support Renzi in his requests and positions when needed.

The European elections victory allowed Renzi to present himself as the only leader of a mainstream party who had defeated Euro-skeptics, thus allowing him to play a pivotal role in the post-electoral negotiations. As Italy had undergone severe budget cuts in the previous years (which the Italian prime minister was smart enough to not repudiate fully), Renzi could claim that Italy was among the virtuous countries. At the same time, showing how the European political landscape had been devastated, he could argue that the austerity imposed on highdebt countries had depressed their economies and that of the whole continent too much, arming the arsenal of Euro-skeptic movements and parties all over Europe.

Hence, Italy, for the first time since the onset of the economic crisis, explicitly called for a revision of the rescue strategy that had been pursued until then. Thanks to Renzi's electoral success, Italy could stop acting simply as a member of the GIIPS group and gain a more central role, while exploiting the crisis of the France-Germany relations after the very close cooperation between the two (dubbed as "Merkozy") at the time of the 2011 financial crisis. ${ }^{27}$ Renzi represented a sort of "third way" that could reconcile the two extremes: the pro-austerity group led by Germany and the anti-austerity strategy promoted by France. This became clear when France announced, at the beginning of October 2014, that it would not respect the 3 percent deficit to GDP limit in 2015. Although the French government was politically very weak, Renzi decided to fully "cover" its president, François Hollande, offering him an explicit endorsement against the "austerity hawks." ${ }^{28}$ What has he got back? First, Renzi can claim that Italy is not Europe's biggest problem anymore, and it can thus afford to deviate from the austerity path, adopting a more expansionary economic policy. Second, his informal leadership has been recognized by all the countries that do not support the austerity coalition.

Renzi's strategy in the making of the new European Commission is also worth analyzing. Just a few days after the elections, it was already clear that Renzi wanted to designate the new High Representative (HR) for Foreign Affairs and Security Policy, and that his first (and only) choice was Italy's foreign minister, Federica Mogherini. The minister appeared as a weak candidate for several reasons. First, she did not seem to have enough experience for such a role. Second, Eastern European countries had found her too pro-Russian during the Ukrainian crisis. Third, Mogherini was not even particularly supported 
by Renzi's coalition at home. These concurrent factors, matched with many negotiators' irritation over Renzi's bargaining strategy, led to no HR appointment at the European Council of 16 July. However, Renzi maintained his position and finally obtained Mogherini's appointment in the European Council of 30 August. As easily predictable, the PES Group at the European Parliament publicly supported Mogherini. ${ }^{29}$ In the context of a progressive "parliamentarization" of the EU, ${ }^{30}$ especially regarding the appointment of the European Commission, the cohesiveness of the socialist group (influenced by the PD's victory in the European elections) was surely helpful. Regarding Renzi's negotiation strategy, he insisted on his initial proposal and chose not to have a "plan B." The method was risky, but in the end successful. It is also worth mentioning that, given president-elect Jean-Claude Juncker's troubles with finding enough women for his Commission, ${ }^{31}$ Renzi's choice helped Mogherini receive a strong endorsement from the president-elect.

In sum, Renzi has so far been successful in using a mix of pro- and anti-EU stances. By doing so, he has achieved a memorable electoral success that has allowed him to acquire more bargaining power at the EU level. This is a position in which the PD, and the center-left in general, has never found itself before. Since decision-making at the EU level is a domain in which national leadership matters more than in other fields, ${ }^{32}$ Renzi's strategy in Europe is likely to have an enduring impact on the PD position with respect to European integration and policy-making.

\section{Renzi, the PD, and the Government: A Veto Players Approach}

Renzi's impact on the government's agenda and on the public perception of the government has been as relevant as in the other domains that have been analyzed thus far. Renzi has seized power very quickly and has shaped the agenda of the government and of Italian politics in general with indisputable success. ${ }^{33}$ He has managed to start a process of electoral and constitutional reform, in which he has involved Berlusconi despite his ban from public office and his exit from the government majority. Compared to Monti and Letta, Renzi has promoted a more expansionary fiscal policy, trying at the same to operate some redistribution to the lower middle class. Looking at the party system, the most significant consequence of Renzi's political action is the importance of the PD and the pivotal position it has acquired. Although the general election of 2013 had given the PD a very high number of 
MPs in the lower chamber, the party's impact on the Letta Cabinet was very limited. How was that possible? And how was Renzi able to increase the power of the PD without any change in the composition of the chambers?

According to the veto players theory, ${ }^{34}$ the number of reforms (changes of the status quo) that a coalition can carry out depends on the number of veto players and on their ideal points: the fewer the veto players and the closer to each other their ideal points, the easier is to pass reforms, and vice versa. In this respect, the Renzi and Letta (since November 2013) Cabinets should have been very similar, being supported by the same parties. However, although the number of parties in the coalition remained the same for the Renzi government, changes in the ideal points of some of them (Renzi's PD above all) have significantly altered the reform capacity of the government and the agenda-setting power of the PD. What follows aims to offer an interpretation of the increase in both the size and the speed of policymaking during the Renzi Cabinet.

To compare the veto players configurations of the Letta Cabinet (April-November 2013 and November 2013-February 2014) with that of the Renzi Cabinet, we can conceive of the political competition taking place in Italy in 2013 and 2014 as a two-dimension one. The first dimension is the traditional right-left divide, which comprises issues pertaining to the redistribution of wealth, labor market flexibility, and levels of taxation. We can assume the left to be in favor of more redistribution, less labor market flexibility, and higher taxation, while the opposite applies for the right. The second dimension covers the degree of support for expansionary policies vis-à-vis austerity ones: the division on this dimension is between parties that see fiscal discipline as a prerequisite for economic growth (in line with the EU approach to the crisis in 20112014), and parties that believe that relaxing austerity and allowing the state deficit to rise in the short term is the only way to return to growth. Given the paramount importance that austerity has acquired in recent years, as well as the impact that it has had on virtually every aspect of policy-making, it is impossible to understand and explain the shifts in the Italian party system without taking it properly into account.

In the first coalition that supported the Letta Cabinet, the three parties were the PD, Berlusconi's Popolo della Libertà (PdL, People of Freedom) and Monti's Scelta Civica (SC, Civic Choice). The two main parties (PD and PdL) had quite distant preferences on the left-right axis, but quite similar ones regarding the need to adopt more expansionary economic policies. The SC, on the contrary, was at the center of the left-right axis but had a strong preference for fiscal discipline-in continuity with the Monti Cabinet. Given the preferences of the actors, 
the opportunity for reforms was very limited because the influence of Monti in the SC made it act as the "guardian" of austerity, while the PD's and PdL's preferences for more expansionary policies could not be realized. The strong austerity constraint of the government was signaled, above all, by its composition, with the key economic ministries (Economy and Finance and Labor and Welfare) removed from the control of the two main parties. Given this set-up, it is not surprising that the government did not decide on anything substantial in terms of economic reforms. Even when the government gave the impression of adopting anti-cyclical and expansionary measures, those were offset by other acts that almost completely outweighed their effects. An example is the abolition of the property tax for 2013, which was strongly requested by the PdL and reluctantly accepted by the other two parties. Although, after tough negotiations, the measure was confirmed, this came at the price of higher taxes in other areas in 2013 and a new property tax in 2014. One can thus argue that the overall status quo was not changed by the Letta Cabinet in its first months.

Contrary to what many expected, the changes that took place in the party system in the autumn of 2013 did not increase the stability and cohesiveness of the government. On the one hand, there was a split in Berlusconi's PdL: this led to the creation of the new Forza Italia (FI), which ceased to support the Letta Cabinet, and the Nuovo Centrodestra (NCD, New Center-Right). Another split, between the liberal and the Christian-Democrat factions, involved the SC and led to Monti's resignation from the party presidency. ${ }^{35}$ Regarding the split in Berlusconi's party, the NCD was explicitly founded on the value of government stability, which implied that it was less "extreme" in both dimensions and more inclined to accommodate the demands of its other coalition partners. On the other hand, FI could go in the opposite direction, trying to capitalize from its new status as an outsider. The split in the SC, instead, derived from divergent attitudes toward the government in Monti's party: the Christian-Democrat component, better represented in the Cabinet, was more willing to make concessions to the other parties for the sake of government stability, while the liberal faction (loyal to Monti) wanted to maintain a more rigid and pro-austerity stance. Since the ideal points of the parties in the coalition continued to diverge strongly on the austerity dimension, all these changes did not significantly alter the reform capacity of the Letta government. As long as the SC was not willing to relax its preference for fiscal discipline, the relative convergence of all the other parties had no substantial impact.

How, then, did Renzi's seizure of power alter the party system configuration? Besides the changes described in the previous paragraph, 
two decisive shifts took place: under Renzi's leadership, the PD sensibly moved toward the center on the left-right dimension and adopted a more expansionary stance on the other dimension. The shift toward the center is illustrated in particular by the tough relationship Renzi established with trade unions and by his more liberal approach to labor market reforms. ${ }^{36}$ The expansionary change is evident when looking at the new relationship that Renzi established with European institutions and with the other EU member states. Concerning the SC, under the new leadership of Stefania Giannini, and because of Renzi's more liberal positions on the economy, the party gradually moved closer to the PD, up to the point that the SC's new president, Alberto Bombassei (who had replaced Monti in November 2013), resigned in April, accusing Giannini and others of having given up all the SC's core values in exchange for government posts. ${ }^{37}$ After the SC, together with two other small parties, got a disappointing 0.72 percent at the European elections, with most of its voters choosing Renzi's $\mathrm{PD}$, prominent SC members started to consider joining Renzi's party. ${ }^{38}$

In practical terms, the shifts that have just been described in the PD and in the SC have made the coalition much more homogeneous than under Letta's prime ministership. Once he took office, Renzi could enjoy greater flexibility in proposing and carrying out reforms. However, there is another crucial difference between the Letta and Renzi Cabinets, and that is the agenda-setting power. In the Letta Cabinet, the prime minister was not the leader of the party. As he had no authority to impose his agenda on his own party, he could not impose it on the rest of the coalition either. The agenda-setting process in the Letta Cabinet was as collegial as the decision-making one: each party came up with its own issues and priorities. In Renzi's Cabinet, instead, the agenda-setting has so far been fully in the hands of the prime minister. Although this does not mean that all the proposals reflect the preferences of only the PD, Renzi's leeway in pushing issues on the agenda is self-evident. Reading the situation under the lens of the veto players theory, the consequence of this transformation is that the policy output can be closer to the PD's ideal point than it was previously. As the convergence between the parties of the coalition has increased, as has the bargaining power of the PD, it is much easier than in the past for Renzi to make proposals that will be accepted by the others. On a side note, it must be observed that the process of convergence described above applies in particular to economic policy choices. In other policy domains, such as justice, security, and LGBT rights, the positions of the coalition parties have aligned to a lesser extent, and the possibility of adopting significant policy changes has therefore been much lower. 
A final remark concerns the electoral strength that the PD of Matteo Renzi has gained in 2014 (see fig. 1). Compared to the electoral consensus of the main parties in 2013, the actual situation in the present coalition reflects a clear "unbalance" of power. The PD is governing with small parties that would probably not elect a single MP if there were elections soon. This makes the potential cost of provoking a government crisis very high for all the PD's coalition partners, which further increases Renzi's bargaining power. It is not very far from the truth to say that the most serious opposition to Renzi today comes from inside the PD.

\section{Conclusions}

This chapter has analyzed the main changes that Renzi has brought about in the PD's governance and ideology, in its attitude toward Europe, and in its position and strength within the party system. All evidence indicates that we are witnessing a radical revolution of the Italian political landscape. The PD's relationship with its traditional allies, its internal decision-making, and its "political supply" have all been deeply affected in just a few months. Mainly because of Renzi's leadership, the party has moved from a share of 25 percent at the 2013 general election to more than 40 percent at the 2014 European elections. As prime minister, Renzi has been able to make the same coalition that supported Letta more cohesive. By making full use of his agenda-setting powers, he has proposed and pushed for the adoption of several important reforms (of the Italian Constitution, of the labor market, of public administration).

Looking at where the PD was in 2013 and where it is now under Renzi's leadership, it would seem obvious to argue that the prime minister has been successful in many respects, in terms of electoral consensus, relationships with other political parties, and policy output. However, it remains to be seen if Renzi will manage to accomplish all the reforms he has promised. He has generated high expectations that, if not met, might create frustration in the electorate. At the time of writing, it is still too early to judge Renzi's long-term impact on the Italian political and economic system. However, it seems unrealistic to imagine that the party system will return to the status quo of 2013, with three relevant parties of roughly the same size. The PD and Renzi seem to have reached a pivotal central position in the party system that is likely to last.

In this respect, the PD's shift toward the center represents both an opportunity and a risk. It is an opportunity because such a central 
position could allow the PD to be the only stable veto player in the party system. It is a risk because it could alienate traditional voters and make the party unappealing to others. A "party of the nation," 39 with a less definite ideology, can attract many voters if it is perceived as credible, as was the case with the European Parliament election. ${ }^{40}$ But it can lose voters quickly if it is perceived otherwise.

Mattia Guidi is a Post-doctoral Fellow at LUISS, Rome.

\section{Notes}

1. Note that non-members are also allowed to participate in the election of the PD secretary. The only requirement is to be registered, which can be done even on the day of the election itself.

2. These elections for party secretary are not real primary elections. See G. Pasquino, "Primary Elections in Italy: An Episode in Institutional Imitation," Journal of Modern Italian Studies 16, no. 5 (2011): 667-684.

3. Two other secretaries, Dario Franceschini (in 2009, after Veltroni stepped down) and Guglielmo Epifani (in 2013, after Bersani's resignation), were appointed by the party assembly to play a sort of "caretaker" role, which lasted a few months in both cases.

4. A. Chiaramonte and V. Emanuele, "Volatile and Tripolar: The New Italian Party System," in The Italian General Election of 2013, ed. L. De Sio, V. Emanuele, N. Maggini, and A. Paparo (Rome: CISE, 2013), 63-68.

5. However, the first relevant election under Renzi's leadership, the regional election in Sardinia of February 2014, was (quite unexpectedly) won by the PD.

6. "Legge elettorale, Renzi lancia 'Italicum'. Minoranza contro, ma proposta passa: Neanche un no," La Repubblica, 20 January 2014.

7. P. Salvadori, "Matteo Renzi, è 'fiduciamania': In otto mesi un voto di fiducia ogni dieci giorni. Prodi, Berlusconi, Letta, Monti: Nessuno mai come lui," L'Huffington Post, 23 October 2014.

8. See J. Blondel and J.-L.Thiébault, eds., Political Leadership, Parties and Citizens: The Personalisation of Leadership (London: Routledge, 2009); P. Webb, T. Poguntke, and R. Kolodny, "The Presidentialization of Party Leadership? Evaluating Party Leadership and Party Government in the Democratic World," in Comparative Political Leadership, ed. L. Helms (Basingstoke: Palgrave Macmillan, 2012), 77-98; T. Poguntke and P. Webb, eds., The Presidentialization of Politics: A Comparative Study of Modern Democracies, 2nd ed. (Oxford: Oxford University Press, 2007).

9. O. Kirchheimer, "The Transformation of the Western European Party Systems," in Political Parties and Political Development, ed. J. LaPalombara and M. Weiner (Princeton, NJ: Princeton University Press, 1966), 177-200. 
10. R. D’Alimonte, "Renzi, alta fedeltà e nuovi voti a $360^{\circ}$," in Le Elezioni Europee 2014, ed. L. De Sio, V. Emanuele, N. Maggini, and A. Paparo (Rome: CISE, 2014), 135-138.

11. In an interview in March, after he had been criticized by the heads of Confindustria (the employers' association) and CGIL, he said that he respected them, but that he is "here for the families, for the employer, for those who do not feel represented." See "Renzi: Squinzi-Camusso strana coppia, non fermeranno le riforme," Il Messaggero, 23 March 2014.

12. "Camusso insiste: 'Renzi come la Thatcher, finora non dialoga,'” Il Secolo XIX, 6 October 2014.

13. "Renzi: 'Innovazione e uguaglianza, la mia idea di destra e sinistra nell'Europa della crisi,”' La Repubblica, 23 February 2014.

14. "Il discorso della vittoria di Renzi," Il Post, 8 December 2013.

15. "Renzi: Un partito di sinistra deve immaginarsi il domani, non limitarsi ad aspettarlo," YouDem, 29 September 2014, http://www.youdem.tv/ doc/272083/renzi-un-partito-di-sinistra-deve-immaginarsi-il-domani-nonlimitarsi-ad-aspettarlo.htm.

16. R. C. Eichenberg and R. J. Dalton (1993), "Europeans and the European Community: The Dynamics of Public Support for European Integration," International Organization 47, no. 4 (1993): 507-534; I. Sánchez-Cuenca, "The Political Basis of Support for European Integration," European Union Politics 1, no. 2 (2000): 147-171.

17. D. Toshkov, "Public Opinion and Policy Output in the European Union: A Lost Relationship," European Union Politics 12, no. 2 (2011): 169-191; K. Armingeon and B. Ceka, "The Loss of Trust in the European Union during the Great Recession since 2007: The Role of Heuristics from the National Political System," European Union Politics 15, no. 1 (2014): 82-107.

18. L. N. Lindberg and S. A. Scheingold, Europe's Would-Be Polity: Patterns of Change in the European Community (Englewood Cliffs, NJ: Prentice-Hall, 1970); S. Hix and B. Høyland, The Political System of the European Union, 3rd ed. (Basingstoke: Palgrave Macmillan, 2011), 107.

19. K. Dyson and K. Featherstone, "Italy and EMU as a 'Vincolo Esterno': Empowering the Technocrats, Transforming the State," South European Society and Politics 1, no. 2 (1996): 272-299; C. Hay and B. Rosamond, "Globalization, European Integration and the Discursive Construction of Economic Imperatives," Journal of European Public Policy 9, no. 2 (2002): 147-167.

20. In spite of this, Italy has always had (and still has) low levels of compliance with EU legislation. See G. Falkner and O. Treib, "Three Worlds of Compliance or Four? The EU-15 Compared to New Member States," JCMS: Journal of Common Market Studies 46, no. 2 (2008): 293-313.

21. J. Tallberg, "Delegation to Supranational Institutions: Why, How, and with What Consequences?" West European Politics 25, no. 1 (2002): 23-46.

22. N. Conti, "Party Conflict over European Integration in Italy: A New Dimension of Party Competition?" Journal of Southern Europe and the Balkans Online 8, no. 2 (2006): 217-233.

23. P. D. Culpepper, "The Political Economy of Unmediated Democracy: Italian Austerity under Mario Monti," West European Politics 37, no. 6 (2014): 1264-1281. 
24. “Monti avverte l'Europa e la Germania: L'Italia sta facendo la sua parte, ora tocca a voi," Corriere della Sera, 12 January 2010.

25. "Letta: 'I sacrifici li abbiamo fatti, ora basta con l'Europa del rigore. Il mondo corre, ma l'Italia può farcela,'” Il Messaggero, 17 August 2013.

26. “Governo: Renzi, dopo mille giorni Italia tornerà leader, non follower," Adnkronos, 1 September 2014.

27. Y. Karagiannis and M. Guidi, "Institutional Change and Continuity in the European Union: The Super-Commissioner Saga,” Acta Politica 49, no. 2 (2014): 174-195.

28. J. Politi, "Matteo Renzi Says Berlin Has No Right to Lecture Its Partners," Financial Times, 2 October 2014.

29. "Socialists Back Mogherini for EU Foreign Affairs Chief," EurActiv, 16 July 2014, http://www.euractiv.com/sections/eu-elections-2014/socialists -back-mogherini-eu-foreign-affairs-chief-303508.

30. B. Rittberger, "Institutionalizing Representative Democracy in the European Union: The Case of the European Parliament," JCMS: Journal of Common Market Studies 50, no. s1 (2012): 18-37.

31. “Juncker Wants More Women in Top EU Jobs,” Euronews, 31 July 2014, http://www.euronews.com/2014/07/31/juncker-wants-more-women-in-top -eu-jobs/.

32. T. Raunio, "Why European Integration Increases Leadership Autonomy within Political Parties,” Party Politics 8, no. 4 (2002): 405-422.

33. M. Guidi, "Politics in a Hurry: The Dizzying Speed of Matteo Renzi," Policy Network, 25 March 2014, http://www.policy-network.net/pno_detail.aspx? ID $=4606 \&$ title $=$ Politics-in-a-hurry-The-dizzying-speed-of-Matteo-Renzi.

34. G. Tsebelis, Veto Players: How Political Institutions Work (Princeton, NJ: Princeton University Press, 2002).

35. Marzio Bartoloni, “Monti lascia scelta civica," Il Sole 24 Ore, 18 October 2013.

36. The Poletti decree (Law No. 78/2014) simplified and extended the renewal of fixed-term contracts. The law establishing a framework for a general labor market reform (still under discussion in Parliament at the time of writing) is expected to further reduce employment protection (see also Picot and Tassinari, this volume).

37. L. Pagni, "Nuova tegola sui centristi: Bombassei lascia la presidenza di Scelta Civica,” La Repubblica, 4 April 2014.

38. S. Turco, "Andrea Romano: 'Io traditore? No, è Renzi che ha fatto propri i valori di Scelta Civica,"' L'Espresso, 21 October 2014.

39. "Renzi alla direzione dem: 'Pd sia partito della Nazione'. Alla minoranza: 'No strutture parallele, venite a Leopolda,'” La Repubblica, 20 October 2014.

40. L. De Sio, “Beyond 'Position' and 'Valence': A Unified Framework for the Analysis of Political Issues,” EUI Working Paper No. 2010/83, Robert Schuman Centre for Advanced Studies, 2010; L. De Sio, "Da dove viene la vittoria di Renzi,” in De Sio et al., Le Elezioni Europee 2014, 171-180. 